\title{
NEGOTIATING THE SOCIAL RELATIONSHIPS THROUGH THE DISCOURSE OF SOCIAL NETWORKING SITES (SNSS) COMMENTING ON WEST JAVA PARAGLIDING WORLD CHAMPIONSHIP (WJPWC) 2019
}

\author{
Suroto $^{1}$ and Ika Yatmikasari ${ }^{2}$ \\ STBA Sebelas April Sumedang ${ }^{1}$, \\ Universitas Islam Negeri Sunan Gunung Djati Bandung ${ }^{2}$
}

\begin{abstract}
The Research analyzes how the social relationships are negotiated through the discourse of social networking sites in the form of Facebook status commenting on West Java Paragliding World Championship (WJPWC) 2019. The analysis focuses on how the participant tells her feelings about things and people through her Facebook status during the WJPWC event. By the qualitative descriptive method, the Facebook status of a paragliding legend was analyzed using the interpersonal metafunction of Halliday's Systemic Functional Linguistics and appraisal theory of Martin and Rose. Using the interpersonal metafunction, the attitudes and judgments of the participant are evaluated based on the speech roles, mood types, and modalities used in the text. The appraisal theory is used for further evaluation to know how the feelings of the participant by evaluating (1) the kinds of attitudes (affect, judgment and appreciation), (2) the attitude resources, and (3) how the attitudes are amplified. The result showed that the participant through her four Facebook status consisted of 26 clauses used the speech roles of giving information in the mood types of declarative. By the mood types, the participant directly and explicitly showed the positive attitudes commenting on the WJPWC event and realized in several linguistic realizations. The participant who roles as the attitude resources expressed her feelings in three main types of attitudes; (1) her positive affect or feelings, (2) her positive judgment of personal and moral, and (3) her positive and negative appreciation of valuing thing during the WJPWC event. The participant also used several metaphors that play important roles in constructing her gradable feelings and emotion.

Keywords: Appraisal Theory, Attitude Evaluation, Interpersonal metafunction, Systemic Functional Linguistics
\end{abstract}

\section{INTRODUCTION}

The event of West Java Paragliding World Championship (WJPWC) 2019, which lasted from 22 to 28 October 2019, is very important for Sumedang especially in supporting the promotion of its tourism objects (Pikiran-rakyat.com, 26 August 2019; Tribunnews.com. 29 September 2019; Newsdetik.com, 10 October 2019). Because of that, the success of the event then must be evaluated for the better same event. Discursively, the evaluation can be drawn from the perspective of the paragliding participants by seeing how they negotiate the social relationships through their discursive practices; written or oral text. This social relationship can be evaluated from what participants feel about things and people through their discursive practices commenting on the WJPWC event.

The present research analyzes the discursive practices of a paragliding legend in the form of written text; the Facebook status commenting on the WJPWC event. 
The Facebook status of Petra Slivova, Czech Republic paragliding legend (Sport.detik.com. 25 October 2019; Katusba.com. 5 November 2019), as one of the WJPWC participants, was chosen as the research object. This is based on the argument that a legend as a very famous person, especially in a particular field, who is admired by other people (Hornby, 2000:734), is very possible to have a lot of experience in taking various events of paragliding competition. By these experiences, a paragliding legend possibly has a better concept in appreciating paragliding events than other participants. Four Facebook status of Petra Slivova were analyzed using the interpersonal metafunction and appraisal theory to know how the attitude and judgment of the participant negotiated in the text.

The research on evaluating the attitude has been done by so many researchers. Some of them are Garcia (2013), Sutherland and Adendorff (2014), Sabao (2016), Cheung and Low (2017), and Li and Zu (2019). Different objects and focuses had been analyzed by those of previous researches. Garcia (2013) explored constitutive features and functions of the discourse of social networking sites (henceforth SNSs) that contribute to defining it as a genre. The corpus used consists of a random sample of 200 messages from university students in the United Kingdom and the United States during 2010-2011. Within Systemic Functional Linguistics (SFL) (Halliday 2004/1994/1985), appraisal theory (Martin and White 2005) is combined with politeness theory (Brown and Levinson 1987) to attempt an explanation accounting for discourse organization in SNSs. Cheung and Low (2017) focused on the student writers' control over evaluative resources that influence the realization of voice in the high-scoring and low-scoring scripts. Using the appraisal system in Systemic Functional Linguistics, the study showed how the voice was construed through appraisal theory in the high-scoring and low-scoring general paper essays, respectively. Sabao (2016) focused on presenting evidence that the linguistic discourse-analytical framework of appraisal theory provides alternative ways of analyzing 'objectivity' and ideological bias in 'hard' news reports. Sutherland and Adendorff (2014) applied a critical appraisal analysis using the full system of Attitude, Graduation, and Engagement and revealed that texts they analyzed used different appraisal resources to align their audiences around different stances, reflecting different communities of shared values concerning gender equality. Meanwhile, $\mathrm{Li}$ and $\mathrm{Zu}$ (2019) used appraisal system to analyze the lexical items that indicate attitudes towards China and other countries with a view to revealing the ways in which China and other countries are appraised in Chinese political discourse. Compared with the previous research, the present research is more similar with the research conducted by Garcia (2013) and Sabao (2016) from the point on the genre that is analyzed; the present research focuses on analyzing the attitude from the discourse of social networking sites in the form of Facebook. Thus, the present research is aimed to strengthen the previous research that focuses on how evaluating the attitude using the appraisal theory of systemic functional linguistics especially the previous research that analyzes how the negotiation of the social relationship between participants through SNSs.

\section{LITERATURE REVIEW}

\section{Interpersonal Meaning}

The Systemic Functional Linguistic model of language in social context focuses on three social functions. These three social functions, known as the 
metafunctions of language, refers to the language that has the function to ; (1) enact our social relationships, (2) represent our experience to each other; and (3) organize our enactments and representations as meaningful text. The metafunction of language involves interpersonal, ideational, and textual metafunctions that are interwoven with each other (Hallyday, 2014:30; Martin \& Rose, 2007:7; Eggins, 2004:2). Further, Martin and Rose(2007:7) said that we can look at any piece of discourse from any of these three perspectives, and identify different functions realized by a different pattern of meaning. The present research looks at Petra's discursive practice from the perspective of interpersonal metafunction or interpersonal meaning.

Interpersonal meaning is meaning that expresses the attitude and judgment of the participant involved in the discourse by the time an interaction took place. Through interpersonal meaning, we see a clause; written or orally, as an exchange (see Halliday; 2014:134). It is because making an utterance is an interactive event involving a speaker or writer and an addressee (listener or reader). Further, a speaker, in uttering, selects a speech role (giving or demanding) for himself and simultaneously allocates a speech role to the addressee. In an interaction, however, will run around two speech roles: giving and demanding. The exchange itself is realized by only two commodities: (1) goods-\&-services and (2) information. The first require actions or non-verbal response, while the second expect verbal one.

Choosing one of the speech roles then is followed by choosing mood types as part of whether a participant positions as the initiator of the interaction or as a responder. The following table describes how interaction takes place.

Table 1. Speech Roles and Speech Function in an interaction

\begin{tabular}{|c|c|c|c|c|}
\hline $\begin{array}{l}\text { Speech } \\
\text { Roles }\end{array}$ & $\begin{array}{l}\text { Exchange } \\
\text { Commodity }\end{array}$ & Initiation & $\begin{array}{l}\text { Supporting } \\
\text { Response (+) }\end{array}$ & $\begin{array}{l}\text { Confronting } \\
\text { Response (-) } \\
\end{array}$ \\
\hline${ }_{1}$ Giving & \multirow{2}{*}{$\begin{array}{l}\text { (1) goods-\&- } \\
\text { services } \\
\end{array}$} & Offer & Acceptance & Rejection \\
\hline${ }_{2}$ Demanding & & Command & Compliance & Refusal \\
\hline${ }_{1}$ Giving & \multirow{2}{*}{ (2) Information } & Statement & Acknowledgment & contradiction \\
\hline${ }_{2}$ Demanding & & Question & Answer & disclaimer \\
\hline
\end{tabular}

Initiation of goods-\&-services and information that includes offer, command, statement, and question are referred to by Halliday as speech functions. All exchanges in a dialogue are initiated by one of these speech functions that results in other speech functions realized by those responses above.

\section{Appraisal}

Martin and Rose (2007:26) state that appraisal is a system of interpersonal meaning or the linguistic realization of interpersonal meaning (Liu and McCabe, 2018:38). The social relationships can be negotiated by telling our listener or reader what we feel about things and people. Appraisal is concerned with evaluation - the kinds of attitudes that are negotiated in a text, the strength of the feelings involved, and the ways in which values are sourced (Martin and Rose, 2007:26). Further, Martin and Rose (2007:59) propose the appraisal system as shown by the following figure. 


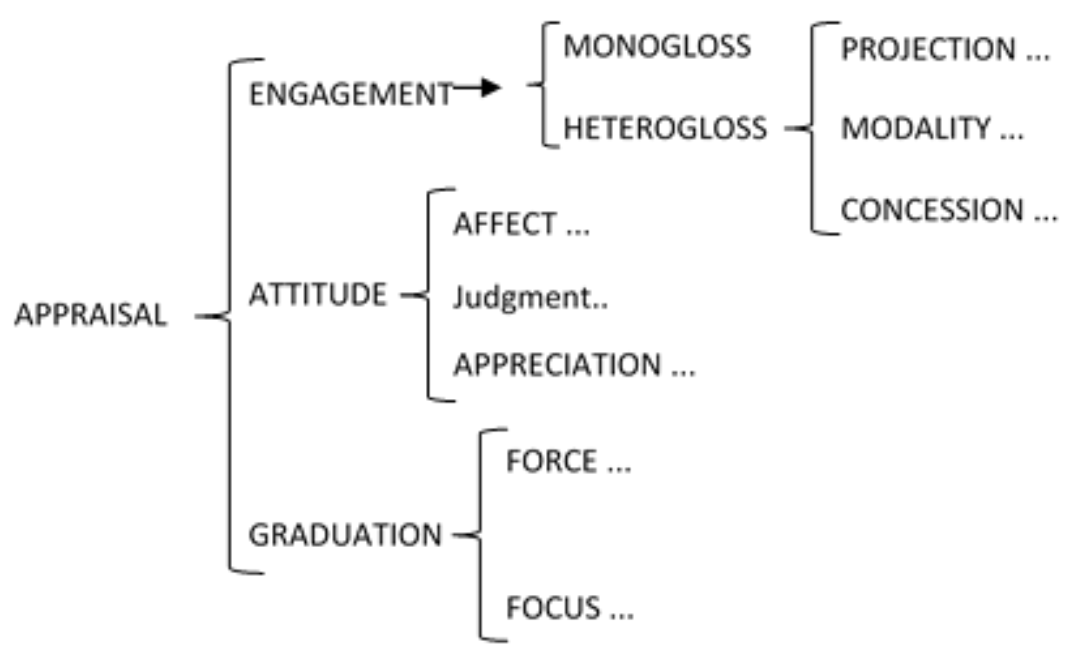

Figure 1. Appraisal System: an overview (from Martin \& Rose, 2009:59)

The following is the explanation for the figure 2 based on Matin and Rose (2007:59). The kinds of attitude involved three main types; (1) affect in the form of expressing emotion, (2) judgment; judging character, and (3) appreciation; valuing the worth of things. The strength of the feelings refers to the amplification; it is how strongly, from low to high, we feel about someone or something. The amplification covers grading, including force and focus; force involves the choice to raise or lower the intensity of gradable items, focus the option of sharpening or softening an experiential boundary. Engagement covers resources that introduce additional voice to discourse, via projection, modalization, or concession; the key here is one voice (monogloss) or more than one voice (heterogloss).

\section{METHOD}

The present research employed qualitative descriptive method (Alwasilah, 2002; Silverman, 2005), in which it is regarded as a compatible methodology for analyzing language phenomena that generally present certain attitudes at most (Dawson, 2009). The Facebook status of the paragliding legend commenting on the event of WJPWC 2019 was analyzed using the interpersonal metafunction of Halliday's Systemic Functional Linguistics and using the appraisal theory of Martin and Rose. The attitude and judgment of the participants, by means of mood system, are evaluated based on the speech roles, mood types, and the modalities used in a text. The appraisal theory is used for further evaluation to know how the feelings of the participant by evaluating (1) the kinds of attitudes (affect, judgment and appreciation), (2) the attitude resources, and (3) how the attitudes are amplified.

\section{FINDINGS AND DISCUSSIONS}

\section{The Speech Roles and mood types}

Four Facebook status of Petra Slivova consists of 26 clauses posted on 23, 25, 27 and 28 October 2019. The classification of clauses as shown by the following figures were according to their speech roles and speech function or mood types. 
Table 2. The Total Classification of the clauses

\begin{tabular}{|c|c|c|c|c|c|c|c|c|}
\hline \multirow{2}{*}{ Text } & \multicolumn{2}{|c|}{ Speech Roles } & \multicolumn{2}{|c|}{$\begin{array}{l}\text { Commodity } \\
\text { Exchanged }\end{array}$} & \multicolumn{4}{|c|}{$\begin{array}{c}\text { Speech Function (MOOD } \\
\text { Types) }\end{array}$} \\
\hline & $\sum_{0}^{\infty}$ & 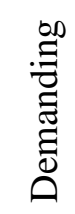 & 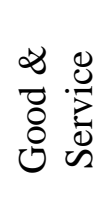 & 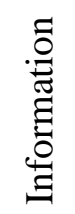 & 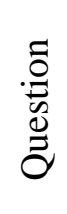 & 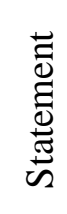 & 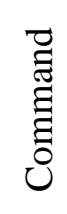 & 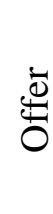 \\
\hline 1 & 8 & & & 8 & & 8 & & \\
\hline 2 & 2 & & & 2 & & 2 & & \\
\hline 3 & 7 & & & 7 & & 7 & & \\
\hline 4 & 9 & & & 9 & & 9 & & \\
\hline $\begin{array}{c}\text { Total } \\
\text { Clauses }\end{array}$ & 26 & & & 26 & & 26 & & \\
\hline
\end{tabular}

The table shows the realization of all clauses in the speech roles of giving and in the mood types of declarative. The declarative mood types indicate Petradirect and explicit expression of her feelings. All commodities exchanged in the discourse is information related to people (local people, competitors) and things (competition and the weather).

\section{The Attitude Negotiated by The Participant Through the Text}

The participant in exchanging the information used a range of attitudes for expressing her feelings. What kinds of attitudes, how the attitudes are amplified, and what source of attitude will be detailly elaborated are as the followings.

Data 1(23 October 2019, 18:26)

(1)Wonderful Indonesia! - name of our team for West Java - Sumedang - competition is really expressing our feelings from this place! (2i)All people are so happy to see paragliding competition and pilots from all around the world here in town Sumedang and (2ii)they are showing the hospitality with big smiles on their faces! (3)We are like a rock star - with our faces on sticker on car and posters... (4)Today we flew first short task to warm up with quite strong and windy conditions. (5i)Congratulation to Pal who won the task, (5ii)I was really happy with stability of my Leopard and arrived to goal as 6 th overall and first lady. (6)Three more days to race, hopefully with less wind.

The first Facebook status was written on 23 October 2019. The participant, as the single resource of introducing the discourse, expresses her positive feelings about the condition and the situation of the first-day paragliding task. She evaluates the weather, local people, and other paragliding competitors.

She begins with her positive attitude by expressing the value of her team's happiness feeling/ affect participated in the WJPWC and for having "Wonderful Indonesia" as the name of her team. This happiness feeling is realized in the verbal and noun group 'is really expressing our feeling'. She also describes the feeling of all people there who are 'so happy' to see paragliding competition and pilots from all around the world. She then turns to the local people's character that she judges very friendly, realized by the phrase 'showing the hospitality with big smiles on 
their faces!'. Further, she metaphorically judges her team to be 'like a rock star' caused by the fact that her faces and team members are on a sticker on cars and posters. Related to the weather, she negatively appreciates by giving attribute 'quite strong and windy conditions'.

She positively judges her friend Pal the winner(won the task). And for her glide that she names Leopard, she positively feels 'really happy' and followed by her positive judgment for the Leopard that is linguistically realized by noun group 'the stability of my Leopard'. She closes her status by expressing hope for the next three more day races realized in the adverbial group 'hopefully with less wind'.

Based on the identification above, Petra at least evaluates three main areas; (1) the value of things, (2) people's character, and (3) people's feelings. And further, Petra is very gradable in expressing those three kinds of evaluation. She describes the people feeling, for example, not just as happy but so happy and really happy. She evaluates the condition (the value of thing) not just strong and windy conditions but a quite strong and windy condition. And for the local people's character, she judges not just friendly but showing the hospitality with big smiles on their faces!. The use of metaphor 'like a rock star' also shows the force of graduation in negotiating attitude.

Data 2(25 October 2019, 13:52)

(1)West Java - Sumedang, Task 2, $47 \mathrm{~km}$. (2)We enjoyed nice flying day

This second Facebook status is the very short status with only two clauses giving information about the second-day paragliding task and how her feeling is. Petra expresses the affect and the value of thing (appreciation).In giving affect, She expresses her team's feelings and realized in the verb enjoyed for having the second-day task. Then she turns to appreciate the condition of the second-day task that is realized in the noun group nice flying day. Compared to the first-day task that is quite strong and windy condition, the second day is better. From this, we know that Petra negatively appreciates that the weather/the wind is unpredictable.

\section{Data 3(27 October 2019, 16:11)}

(1)Sumedang competition is over! (2)We flew 3 sportive tasks. (3)Congratulation to Korean pilot Chigwon Won who won! (4)I finished 1st female and 4th overall. (5)Gin Leopard rocks!!!(6i)Our team of legends named Wonderful Indonesia by me, Felix, Pal and Veso took also gold, (6ii)so time to celebrate.

The third status of Petra consists of seven clauses giving information that the WJPWC 2019 is over. She evaluates the value of things; tasks and her team. She appreciates that her team has experienced 3 sportive tasks. By means of sportive, she positively appreciates that her team experienced three fair and challenging tasks. She also appreciates her team that 'rocks' during the task and as 'team of legend' who has also taken gold. Using the verb 'rock' here she positively appreciates her team for having the gold, the thing that makes everyone feeling shocked but in the positive sense. And her team success makes that day deserve for having attribute time to celebrate. 
(1i)If you are lucky, (1ii)all is possible! (2i)By entering the plane in Jakarta (2ii)they informed me (2iii)I was rebooked for bussiness class for my 11 hours flight... (3i)Is it just good luck or (3ii)is there involved the fact that I was like a big star in Indonesia and shaking hand to the governor of West Java yesterday??? (4i)Does not matter, (4ii)now I am real winner!

This last facebook status consists of nine clauses giving information about her feeling and experience of her way back to her country by plane. Petra evaluates the value of thing (appreciation) and the people feeling (affect). A moment that results in her positive unpredictable feeling is that someone has rebooked her flying to the business class. She morally appreciates that such a situation is possible if we are lucky. She then tries to correlate her luck with the feeling that she was like a big star in Indonesia and her experience of shaking hands to the governor of West Java the day before. If it is true that shaking hands with the governor of West Java be the cause of the rebooked, it shows the positive service of the government. Whatever it is, the lucky situation has also made her feeling likes the real winner.

The source of attitudes from this last Facebook status is not only Petra. From the projecting clause, they informed me, the participant they is another source of attitudes. The pronoun they refers to the airport department workers. They informed a piece of good news for Petra; she was rebooked to business class. Further, Petra's evaluation of her feeling is also gradual. She calls herself not only as a winner but as a real winner. The use of metaphor like a big star in Indonesia also gives the force or strengthens her affect or feeling.

\section{CONCLUSIONS}

The findings show the detailed analysis of how Petra negotiates her social relationship by expressing her feelings toward people and things through her four Facebook statuses. The four Facebook statuses consist of 26 clauses that are realized in the speech roles of giving information and in the mood types of declarative. This shows that Petra directly and explicitly wants to express her feeling. Two resources of attitude (engagement) found in the four Facebook status; Petra (the dominant source of attitudes) and the airport worker. Petra runs into three main types of attitude; (1) expressing people's emotion (affect), (2) judging people's character and (3) valuing the worth of thing (appreciation). These attitudes are also gradable by means of adjective intensifier and metaphor. The interesting finding is that most types of attitudes are expressed positively; the affect, the local people's character, and the value of everything except the weather is all positive. Practically, this can be recommended for the committee and the government to at least maintain the quality of next WJPWC. 


\section{REFERENCES}

Alwasilah, A. C. (2002). Pokoknya Kualitatif: Dasar-dasar Merancang dan Melakukan Penelitian Kualitatif. Bandung: Pustaka Jaya

Cheung, L.Y. \& Low. T.H. (2017). Pre-university Students' Voice Construction in Argumentative Essays. RELC Journal, 00 (0), 1-16. doi:10.1177/0033688217716508

Eggins, S. (2004). An Introduction to Systemic Functional Linguistics. $2^{\text {nd }}$ edition. London: Continuum.

Garcia, C.S. (2013). The discourse of social networking sites in university Students' communication with their peers. Journal of science and medicine in Sport, 13(6), 578-583. doi:10.1016/j.jsams.2010.03.007

Gerot, L. and Wignell, P. (1994). Making Sense of Functional Grammar. Cammeray, NSW: AEE.

Halliday, M.A.K. (2014). Hallyday's Introduction to Functional Grammar (Fourth edition). London: Routledge.

Horby, A.S., (2000). Oxford Advanced Learner's Dictionary of Current English. UK; Oxford University Press.

Li.T., and Zu.Y. (2019). How does China appraise self and others? A corpus-based analysis of Chinese political discourse. Journal of Discourse and Society, 1-19. 00(0) doi: 10.1177/0957926519880036

Liu, Xinghua., McCabe, Anne. 2018. Attitudinal Evaluation in Chinese University Students' English Writing; A Contrastive Perspective. Singapore: Springer.

artin, J.R., and Rose, D. (2007). Working With Discourse; Meaning Beyond the Clause. Great Britain; Continuum.

Sabao, C. (2016). Arguments for an appraisal Linguistic discourse approach To the analysis of 'objectivity' in 'hard' news reports. African Journalism Studies, 37(1), 40-63. doi: 1080/23743670.2015.1095776

Publications

Silverman, D. (2005). Doing Qualitative Research. London: Sage

Sutherland, A., \& Adendorff, R. (2014). An Appraisal analysis of a Women's Day rant, rally and reflection. Southern African Linguistics and Applied Language Studies, 32(4), 393-415. doi: 10.2989/16073614.2014.997070

\section{Internet Sources}

Katusba.com. (2019). WJ Paragliding World Championship 2019, Petra Slivova: I'm a little bit surprised!. Retrieved from https://katusba.com/katusbasports/wjparagliding-world-championship-2019-petra-slivova-im-a-little-bit-surprised/

News.detik.com, (2019). Event Paralayang Terakbar Siap Digelar di Sumedang. Retrieved from https://news.detik.com/adv-nhl-detikcom/d-4741675/eventparalayang-terakbar-siap-digelar-di-sumedang 
Pikiran-rakyat.com, (2019). Gelar Kejuaraan Paralayang Internasional, Sumedang Menuju Daerah Destinasi Wisata Kelas Dunia. Retrieved from https://www.pikiran-rakyat.com/jawa-barat/2019/08/26/gelar-kejuaraanparalayang-internasional-sumedang-menuju-daerah-destinasi-wisata-kelasdunia

Tribunnews.com. (2019). Sumedang Promosikan Destinasi Wisata Melalui Kejuaraan Paralayang Internasional. Retrieved from https://www.tribunnews.com/sport/2019/09/28/sumedang-promosikandestinasi-wisata-melalui-kejuaraan-paralayang-internaslonal

Sport.detik.com. (2019). Cuaca Cerah, Peserta Selesaikan Hari Kedua Paralayang di Sumedang. Retrieved from https://sport.detik.com/sport-lain/d-4760033/cuacacerah-peserta-selesaikan-hari-kedua-paralayang-di-sumedang. 